\title{
Brand Equity on Purchase Intention Consumers' Willingness to Pay Premium Price Juice
}

\author{
Ariesta Bougenvile ${ }^{1}$ Endang Ruswanti ${ }^{2}$ \\ Magister Management Esa Unggul University
}

\begin{abstract}
Building the brand equity becomes an important source of differentiation. The company needed to improve competition, because the brand equity is very important to strengthen the company's reputation.However, there are only few studies on beverage value from the consumers' standpoint. And most of the researches had focused in the variables of marketing mix influencing consumers, such as price, communication, distribution or advertising. Congruence with this issue, the research have two objectives, the first objective is understanding consumer mind through brand equity in purchasing a product and willingness to pay premium price. The second is how the strategy should be done by a newcomer to the juice category. Based on sample of 330 consumers, Structural Equation Modeling is used to test hypotheses. The research shows that brand loyalty of juice is the most important dimension to build brand equity. In addition, a positive significant effect is found for brand awareness and association. Meanwhile, weak support is found for the perceived quality dimensions.Empirical support to the effect of juice's brand equity impacts on the consumers' purchase intention and willingness to pay premium price. This research brings relevant implication to the manager of juice production that should consider the relative importance of brand equity dimensions in their overall brand equity evaluationsin creating the consumers' purchase intention and willingness to pay premium price.
\end{abstract}

Keywords: Brand Equity, Purchase Intention, Willingness Premium Price

\section{Introduction}

The rapidly developing beverage industry in Indonesia makes Indonesia one of profitable hub for beverage company. The phenomenon is that globalization development has increased the consumers' need for ready-to-drink (RTD) beverage as the income increase, lifestyle changes, beverage function shifts, need for supplement nutrition increases and consumer's demand for practicality increases.Kotler and Armstong (2008) stated that brand is not only a name and symbol but also a key element in the relationship between company and consumer. The importance of a brand is because it provides a media for the consumers to differentiate one similar product from another. For that reasons, brand equity can be stated as a brand's strength promising the value expected by the consumer in a product so that the consumers will feel more satisfaction with the product used than with other similar products. The competition is getting tighter between brand operated in the market, only product with strong brand equity that will be able to compete, to seize and to master the market.However, there are only few studies on beverage value from the consumers' standpoint (Atilgan et al., 2005). And most of the researches had focused in the variables of marketing mix influencing consumers, such as price, communication, distribution or advertising (Yoo et al.,2000). Nevertheless, in the purchasing process, consumers are not only concerned about the price or quality of a product or brand, but also other variables such as the brand equity or value.

Juice is a beverage with rapid growth in both volume and value in Indonesia. Considering a retail audit conducted by Nielsen 2016, it can be found that juice grows 13\% in value and 18\% in volume from 2013 until 2015. Based on Nielsen's audit retail 2016, the market share of juice in Indonesia is covered $60 \%$ by two giants that are Minute Maid and Floridina. The producer always attempts to produce and to offer the product that generates the consumers' interestedness in purchasing in high frequency and repeatedly. In current research the authors wants to conduct a research on juice beverage as the research object, by modifying and adding each indicator of each variable. The objective of research is firstly to find out the factors affecting an individual in purchasing a product, when faced with many choices, in which the authors will focus on the elements of brand equity including brand awareness, perceived quality, brand association and brand loyalty, thereby generating purchasing intention (short-term) and willingness to pay premium price (long term). Secondly, it aimed to find out what the newcomers, particularly companies that will perform in juice, in order to be competitive along with the successful competitor in beverage world.

\section{Literature Review}

\section{Relation Brand Equity,Purchase IntentionWillingness to Pay Premium Price}

Building a strong brand has been the marketing priority for many companies today because it gives some advantages of building and creating an identity for a company in the market, while becoming the main source of competitive advantage (Aaker,2007). In the attempt of measuring the overall value of brand or product, market researchers and manager have begun to study the concept of brand equity referring to a very 
great value the brand brings to consumers and producer. Stated that brand equity is a series of brand asset and liabilities related to a brand, its name and symbol that adds and reduces the value a product or a service gives to company and/or its customer. Explained asset of brand contributing to creating brand equity into five dimensions, such as brand awareness, perceived quality, brand association and brand loyalty. The first dimension is brand awareness. The second dimension is perceived quality or the perception on quality that can be defined as customers' perception on the whole quality or advantage of a product or service related to what expected by the customers (Muafi and Effendi, 2001).

Meanwhile, according to Durianto, et al (2001), the discussion of customers' perceived quality on product and or attribute the product has (customers' different interest). Perceived quality includes everything related to how a brand is perceived so that through the identification of customers' perceived brand quality, the company can determine the measures to be taken in order to confirm the customers' perceived brand quality the company has. Perceived quality is affected by two dimensions: product quality and service quality (Lindawati,2005). The third dimension of brand equity is brand association. The association is not only exists but also has power level. Association is the attribute existing in the brand and it will be greater when customers have many experiences with the brand. A variety of association remembered by consumers can be combined to create brand image. Argued that brand association builds on three elements: perceived value, brand personality, and organizational association. Brand association has certain power level and will be stronger as the consumers experience with or exposure to the specific brand increases.

Considering the definition above, it can be concluded that brand association is everything related to perception, trust and recall about a brand.The fourth dimension is brand loyalty. This measure can describe whether or not a customer potentially switches to other brand offered by competitor, particularly when there is a change in the brand, pertaining to either price or other attribute. A very loyal customer to a brand will not be able to switch their purchasing to other brand, whatever occurring with the brand. Schiffman and Kanuk (2009) stated that brand loyalty is that brand loyalty is assessed from brand attitude with repeated purchasing. The loyal customers generally will continue the brand purchasing despite many alternative competitor product brands offering the product with more superior characteristics viewed from a variety of its attribute aspects. If many customers of a brand belong to this category, it means that the brand has strong brand equity.

Several definitions of purchase intention have been suggested by some previous researchers. Purchase intention is the decision making process conducted by consumers before conducting purchase transaction over certain product needed by the consumers (Anoraga, 2000). Febryan (2010) stated that purchasing interest can be realized when the criteria consistent with the customers' want. Purchase intention often does not come in the mind sometimes becoming the customers' reason of not purchasing product or service they have often purchased. Purchase interest, according to Ferdinand (2006) can be identified through the following variables. The first is transactional interest, the tendency to purchase a product. The second is preferential interest, the interest representing an individual's behavior with primary preference to the product. The third is exploratory interest, the one representing an individual's behavior always searching for information on the product he/she prefers to support the positive characteristics of product.

Based on Porral, et al. (2013) study, it is mentioned that a brand attains premium price when the number of customers willing to pay a product of a brand is larger than the number of those willing to pay the similar product of other similar relevant brand (Aaker, 2007). Conceptually, some researchers describe premium price as most useful indicators of brand equity (Blackstone, 1995;Aaker, 2007; Sethuraman, 2000). Netemeyer et al (2004) defined the willingness to pay premium price as the number of consumers willing to pay to purchase a brand they prefer compared with the similar/smaller brand. Similarly with Rio, Vazquez, and Iglesias (2001) studying a relationship between the guarantee of a brand and the willingness to pay premium price stated that the more positive the perception on guaranteed product, the more is the willingness to pay premium price among the consumers. Then, overall brand equity affects dependent variable, purchase intention and willingness to pay premium price.Many researches showed that the consumers that can identify the brand name in product category tends to purchase the brand, because the well-known product is usually preferable than the strange one (Hoyer, 1990). Asif, et al. (2015) mentioned that brand awareness affects the establishment of brand equity. For that reason, the brand will likely be taken into account in purchasing decision, when improving brand awareness of certain juice brand. Therefore, the authors proposes the following hypothesis:

\section{$\mathrm{H}_{1}$ : There is an effect of brand awareness on brand equity.}

The quality perceiver from the brand is because of their subjective perception process, involved in decision process. Zeithaml (1988) mentioned the quality felt is the global result of different stimulus experience that can be used as a global assessment on a brand's competitive quality. For that reason, the authors proposes the following hypothesis: 


\section{$\mathrm{H}_{2}$ : There is an effect of perceived quality on brand equity.}

The consumers believe that when a product has a good brand association, it will affect their purchasing behavior. This statement is confirmed by Korchia (2004) study finding that the product with a brand having positive and unique association has high brand equity level. Brand equity level is clearly higher when there are two unique and positive associations. Interestedness is dependent on the association in similar way to brand equity. Maximum level is due to favorable and unique association. So, the following research hypothesis is proposed.

\section{$\mathrm{H}_{3}$ : There is an effect of brand association on brand equity.}

Brand loyalty has been found affecting the brand equity directly and positively (Atilgan, et al.,2005). It is confirmed by the research conducted by Subramaniam, Mamun, Permarupan and Zainol (2014) mentioning that brand loyalty and brand image highly affects the brand equity. Out of the three factors included in regression model, brand loyalty has a higher effect on brand equity compared with brand image and perceived quality. For that reasons, the authors hypothesizes that brand loyalty of juice affects brand equity. Therefore, the authors proposes the following hypothesis.

\section{$\mathrm{H}_{4}$ : There is an effect of brand loyalty on brand equity}

Consumer-based brand equity has been considered as the condition or requirement for brand choice or preference, in turn affecting the purchasing intention. Some studies showed positive relationship between the dimensions of brand equity, brand preference and purchase intention (Vakratsas and Ambler, 1999;Myers, 2003). Therefore, the following hypothesis is proposed:

\section{$H_{5}$ : There is an effect of overall brand equity on purchase intention.}

Brand equity likely affects the consumers' willingness to pay premium price for a product or brand (Arvidsson,2006). Brand equity in commercial brand affects the consumers' response to the increased product price, so that their response to price increase is more elastic (Keller, 2003). In addition, some researchers show that the consumers are willing to pay higher price for the brands with positive brand association (Erdem, etal., 2002; Netemeyer, etal.,2004). Therefore, the following hypothesis is proposed:

$\mathrm{H}_{6}$ : There is an effect of brand equity on willingness to pay premium price.

\section{Research Method}

In this study we chose juices as product categories, as is widely popular in Indonesia. To analyze brand equity, we chose two brands of the same product category, i.e Minute Maid and Floridina. Brands selected for this study well-known, popular and available for Indonesian consumers at every point of sale. In accordance with the analysis tools we use that Structural Equation Model (SEM). A three hundred thirty three respondents are used as a research sample, and the number have met the minimum requirements of Hair et al. (2010), which is $\mathrm{n}$ observations $\mathrm{x} 5$, in which the number of observation variables are 30 questions.In operating variables, we used five point likert scale as measurement scale, in which 1 indicates strongly disagree and 5 indicates strongly agree. The pretest shows that the instrument is valid (factor loading $>0.5)$, reliable $(\alpha=0.663)$, and this construct has been qualified (Hair et al.,2010).In our research, there are independent, dependent and intervening variables. Those variables are as follows, first are independent variables includes brand awareness, perceived quality, brand association and brand loyalty. The second are dependent variables in this research includes purchase intention and willingness to pay premium price. The third is anintervening variable in this research is overall brand equity. To measure brand awareness, there are four indicators used items suggested by Yoo, et al. (2000) and Netemeyer, et al. (2004)and Fayreneand Goi (2011), referring to general knowledge of consumers about the brand and their ability of distinguishing and identifying the brand over other competitors' brand. Furthermore to evaluate the perceived quality, there are four indicators. The items used are those from Porral, et al.(2013), Baalbaki (2012); Anselmsson, et al. (2013) assessing the perceived quality regardless special attribute for certain product category.

Assess brand association, there are seven indicators, in which we use the items used by Porral, et al. (2013), Khan, et al. (2015); Chieng, et al. (2011). To measure brand loyalty, there are five indicators; we use a variety of items suggested by Porral, et al. (2013), Anselmsson, et al. (2014) and Khan, et al. (2015) analyzing whether or not the consumers are considered as loyal to certain brand and if the brand is the first choice, even if they will not buy other brand when this brand is not available in the sale point. In the attempt of assessing overall brand equity, there are four indicators. We use the items suggested by Porral, et al. (2013); Sanyal and Datta (2011). In the attempt of evaluating purchase intention we use four indicators adopted by Porral, et al.(2013); Khan, et al. (2015). For the willingness to pay premium price, there are three indicators. We use the items suggested by Porral, et al.(2013); Anselmsson,et al. (2014). 


\section{Measurements}

Subsequently, from the measurement dimension displayed in the form of questionnaire, we conduct validity and reliability test. Validity test is carried out using Confirmatory Factor Analysis by means of considering Kaiser-Meyer-Olkin Measure of Sampling (KMO) andMeasures of Sampling Adequacy (MSA) values. In this test, the value achieved should be more than 0,5 , meaning that the factor analysis is appropriate or suitable, and the research can be continued. The scale of all variables yielded valid values. The reliability test obtained Cronbach Alpha value > 0,6, meaning reliable, or the indicators of all variables were reliable as the instrument of collecting data in the research. In the next stage, the data was processed using Structural Equation Modeling analysis method. SEM can explain the variable relationship complexly and the direct and indirect effects of one or some variables on other variable (Hair, Black and Babin, 2013). Table 1 shows the measurement scale and indicator used, and the latent variable to be analyzed.

\section{Result}

The measurement model is the one to determine the relationship between latent variables, determining the variables affecting the change of value in latent variable, both directly and indirectly. The criteria of indicator are considered as valid when it has loading factor $>0.5$, with significant t-value $(>1.96)$. From the data processed, it can be found that all values of loading factor are significant with t-value $>1.96(\alpha=5 \%)$. It means that all indicator variables measuring the latent variable have valid value.Reliability test is used to show the consistency of indicators in using each of its latent variables. The tests used are construct reliability and variance extracted. The criteria of measurement test is that construct reliability should be $\geq 0.7$, while variance extracted $\geq 0.5$. Our findings that most of testing values are above the tested criteria, except the reliability construct for brand awareness existing on the accepted marginal limit (0.659), while variance extracted value for latent variable (brand awareness) is below the tested criteria $(<0.5)$.

According to the results obtained for the structural modeling adjustment, ChiSquare is significant, so that it could be considered a reliable indicator of model fit (Bollen, 1989). Other absolute measures of modeling adjustment (Root Mean Square Error of Approximation) show good results, given that the former approach 0,05 value. GFI's value is still below the criteria $(0,812)$, but the value according Hair, etal. (1998) is still in the stage of acceptance limit (marginal acceptance level). For incremental value show good result $>0,9$ value. From the individual parameter test on the structural model shown that it can be seen that latent variables of brand loyalty, brand association and brand awareness affect significantly brand equity with t-value more than 1.96 (level $\alpha=$ $5 \%$ ). Meanwhile, from the model testing, it can be seen that overall model can be stated as good because the coefficient of determinacy value is large enough, 0.866. It indicates that $87 \%$ of information in brand equity variable can be explained by brand awareness, perceived quality, brand association and brand loyalty.

Table 2: Analysis of Structural Model and Test of Research Proposed Hypotheses

\begin{tabular}{|c|c|c|c|c|}
\hline Latent Variable Exogenous $\rightarrow$ Endogenous & $\begin{array}{l}\text { Estimation } \\
\text { Standardized }\end{array}$ & T-Value & $\begin{array}{l}\text { Structural Equation } \\
\text { Coefficient of } \\
\text { Determination }\left(\mathbf{R}^{2}\right)\end{array}$ & Remarks \\
\hline Brand Awareness $\rightarrow$ Brand Equity & 0,201 & 3,314 & \multirow[t]{4}{*}{0,866} & Supported \\
\hline Perceived Quality $\rightarrow$ Brand Equity & 0,045 & 0,490 & & Not Supported \\
\hline Brand Association $\rightarrow$ Brand Equity & 0,267 & 2,640 & & Supported \\
\hline Brand Loyalty $\rightarrow$ Brand Equity & 0,672 & 5,539 & & Supported \\
\hline Brand Equity $\rightarrow$ Purchase Intention & 0,944 & 12,050 & 0,890 & Supported \\
\hline Brand Equity $\rightarrow$ Willingness Premium Price & 0,868 & 15,669 & 0,753 & Supported \\
\hline
\end{tabular}

From the four factors affecting brand equity, brand loyalty has the largest direct effect of $45 \%$ $\left(=0.672^{2} * 100 \%\right)$. Meanwhile the latent variable with smallest effect on brand equity is perceived quality, $0.02 \%$ $\left(=0.045^{2} * 100 \%\right)$. The relationship of brand equity to purchase intention and willingness to pay premium price is indicated with structural relationship between endogenous latent variable. From the two parameter tests, it can be found the significant value (t-value>1.96) and $\mathrm{R}^{2}$ value $89 \%$ and $75 \%$ so that the result of test shows that information from latent variables of purchase intention and willingness to pay premium price can be explained well by brand equity. This model shows that the direct effect of brand equity on purchase intention is $89 \%$ $\left(=0.944^{2} * 100 \%\right)$, while direct effect of brand equity on willingness to pay premium price is $75 \%$ $\left(=0.868^{2} * 100 \%\right)$.

From Table and Figure 2, summarizing the result of first hypothesis $\left(\mathrm{H}_{1}\right)$ testing, it can be found that the result of analysis supports $\mathrm{H}_{1}$, brand awareness affects brand equity. The second is perceived quality $\left(\mathrm{H}_{2}\right)$ testing, it can be found that the analysis does not affect hypothesis that there is an effect of perceived quality on brand equity of product.From the result of third hypothesis $\left(\mathrm{H}_{3}\right)$ testing, it can be found that brand association supports hypothesis that there is an effect of brand association on the establishment of a product' brand equity.From the result of fourth hypothesis $\left(\mathrm{H}_{4}\right)$ testing, it can be found that the analysis supports the hypothesis that there is an effect of brand association on a product's brand equity establishment. From the result of fifth 
hypothesis $\left(\mathrm{H}_{5}\right)$ testing, it can be found brand equity affects purchase intention.From the result of sixth hypothesis $\left(\mathrm{H}_{6}\right)$ testing, it can be found that brand equity affects the willingness to pay premium price.

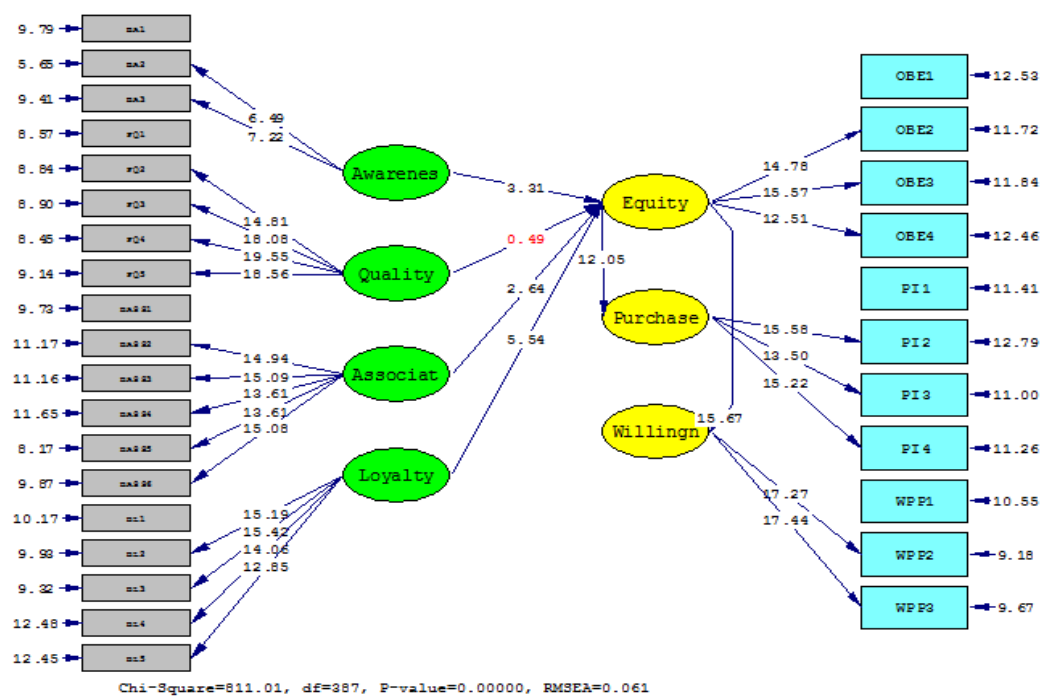

Figure 2. Path Diagram T-Value

Output of path diagram is shown in figure 2, in which hypothesis 1 (brand awareness affects to juice overall brand equity) is supported ( $\mathrm{t}$ value $=3.314$ ), hypothesis 2 (perceived quality affects to juice overall brand equity) is not supported ( $\mathrm{t}$ value $=0.490$ ), hypothesis 3 (brand associationaffects to juice overall brand equity) issupported ( $\mathrm{t}$ value $=2.640$ ), hypothesis 4 (brand loyalty affects to juice overall brand equity)is supported ( $\mathrm{t}$ value $=5.539)$, hypothesis 5 (Overall brand equity affect to juice purchase intention)is supported ( $\mathrm{t}$ value $=$ 12.050) and hypothesis 6 (Overall brand equity affect to juicewillingness to pay premium price)is supported ( $\mathrm{t}$ value $=15.669)$. All the hypothesis are supported except hypothesis 2 , this is not consistent with the previous researches, such as Porral, et al. (2013), Jalilvand, et al. (2011), Severi danLing (2013);Khan, et al. (2015) which stated that perceived quality, influenced the overall brand equity.

\section{Discussion}

Based on summarizing the result of first hypothesis $\left(\mathrm{H}_{1}\right)$ testing, it can be found that the result of analysis supports $\mathrm{H}_{1}$, brand awareness affects brand equity. This result of research confirms the result of previous studies (Asif, et al., 2015 andPorral, et al., 2013) finding that brand awareness affects the establishment of brand equity of product. From the result of second hypothesis $\left(\mathrm{H}_{2}\right)$ testing, it can be found that the analysis does not affect hypothesis that there is an effect of perceived quality on brand equity of product. It is in line with the result of previous study (Atligan, et al., 2005) finding that perceived quality has weak value on creating brand equity in beverage product. From the result of third hypothesis $\left(\mathrm{H}_{3}\right)$ testing, it can be found that brand association supports hypothesis that there is an effect of brand association on the establishment of a product' brand equity. It is also in line with Porral, et al. (2013) stating that brand association affects significantly a product's brand equity. If brand association improves, the brand equity of product would improve because it is viewed from its result, that is, affecting positively.From the result of fourth hypothesis $\left(\mathrm{H}_{4}\right)$ testing, it can be found that the analysis supports the hypothesis that there is an effect of brand association on a product's brand equity establishment.

It is in line with Asif, et al. (2015); Porral, et al. (2013) stating that there is a positive significant effect of brand loyalty on brand equity of a brand. From the result of fifth hypothesis $\left(\mathrm{H}_{5}\right)$ testing, it can be found brand equity affects purchase intention. It is in line with Morandi and Zarei (2015); SenthilnathaandTharmi (2011); Huang, et al. (2014) mentioning that brand equity affects purchase intention. From the result of sixth hypothesis $\left(\mathrm{H}_{6}\right)$ testing, it can be found that brand equity affects the willingness to pay premium price. It is in line with Porral, et al. (2013),Anselmsson, et al. (2014),andKempen (2004) finding that there is a positive significant relationship between strong brand equity and willingness to pay premium price.In the managerial practice, the outcome of this research has given valuable feedbacks which can be used for designing different strategies to attract customers with emphasizing on brand equity of the products and services. Marketers should remember that there are some factors influence consumer's perception towards brand equity. Based on the results from this research finding, marketers should prioritize brand equity constructs as their strategy to attract potential customers because it does show significant direct the dimensions of brand equity to purchase intention and consumers' willingness price. 


\section{Limitations and Future Research}

The limitations of research are firstly related to place (location), because the respondents are limited to those in Indonesia (Greater Jakarta). This fact gives a provisional character to the conclusions reached, and we understand that for this reason it is not possible to broadly generalize our conclusions. We consider that the present research provides a good approach to the RTD juices in Indonesia market, despite future research should include some other countries and markets, in order to analyze whether the obtained results may be generalized.Second, we should address other interesting dimensions of brand equity that have been proposed in the literature, but we have not addressed in this study, such as the country of origin, brand attitude, brand preference, advertising, promotion, price, product quality, and other factors affecting purchase intention and willingness to pay premium price.Finally, our study is focused in one unique product

\section{Reference}

[1]. Aaker, D.A. (2007). Manajemen Ekuitas Merek: Memanfaatkan Nilai dari suatu Merek. Cetakan Ketiga. Jakarta: Penerbit Mitra Utama.

[2]. Anoraga, Pandji. (2000). Manajemen Bisnis. Jakarta: PT. Rineka Cipta

[3]. Anselmsson, K.J., Bondesson, N.V., \& Johansson, U. (2014). Brand image and customers willingness to pay a price premium for food brands. Journal of Product \& Brand Management 23/2 (2014) 90-102 Emerald Group Publishing Limited.

[4]. Arvidsson, A. (2006). Brands Meaning and Value in Media Culture. London \& New York: Routledge Taylor \& Francis Group.

[5]. Asif, M., Abbas, K., Kashif, M., Hussain, S., \& Hussain, I. (2015). Impact of Brand Awareness and Loyalty on Brand Equity. Journal of Marketing and Consumer International Peer reviewed Journal Vol.12.

[6]. Atilgan, E., Aksoy, S., \& Akinci, S. (2005). Determinants of the brand equity A verification approach in the beverage industry in Turkey.Marketing Intelligence \& Planning Vol. 23 No. 3, 2005 pp. 237-248 q Emerald Group Publishing Limited 0263-4503 DOI $10.1108 / 02634500510597283$

[7]. Baalbaki, S.S. (2012). Consumer Perception of Brand Equity Measurement: A New Scale.Dissertation Prepared for the Degree of Doctor of Philosophy. University of North Texas.

[8]. Blackstone, J.H., Fogarty, W.D., Thomas, R. (1991). Production \& Inventory Mangement. Ohio : South-Western Publishing.

[9]. Chieng, F.Y.L., \& Goi, C.L. (2011). Customer-based brand equity: A study on interrelationship among the brand equity dimension in Malaysia. African Journal of Business Management Vol. 5(30), pp. 11856-11862, 30 November, 2011.

[10]. Durianto, D., Sugiarto \& Sitinjak, T. (2001). Strategi Menaklukkan Pasar Melalui Riset Ekuitas dan Perilaku Merek. Jakarta: Gramedia Pustaka Utama.

[11]. Erdem, T., Swait, J., \& Louviere, J. (2002). The impact of brand credibility on consumer price sensitivity. International Journal of Research in Marketing 19 (1), 1-19.

[12]. Fayrene., Y.L., Chieng., Chai., dan Goi, L. (2011). Customer-Based Brand Equity. Journal Of Arts Science \& Commerce. A Literature Review

[13]. Febryan, F. (2010). The Power of Selling: Memperlakukan Pelanggan Sebagai Sahabat Sejati. Jakarta: Elex Media Komputindo.

[14]. Ferdinand, A. (2006). Metode Penelitian Manajemen. Semarang. Badan Penerbit Universitas Diponegoro Semarang.

[15]. Hair, J. F., Black, W. C., \& Babin, B. J. (2013). Multivariate Data Analysis (7 ed.). New York: Pearson.

[16]. Hoyer, W.D., \& Brown, S.P. (1990). Effect ofBrand Awareness on Choice for a Common, Repeat-purchase Product. Journal of Consumer Research. Vol. 17, pp.141-148.

[17]. Huang, C.C., Yen, S.W., Liu, C.Y., \& Chang, T.P. (2014). The Relationship Among Brand Equity, Customer Satisfaction, and Brand Resonance to RePurchase Intention of Cultural and Creative Industries in Taiwan. International Journal of Organizational Innovation (Online) $6.3: 106-120$.

[18]. Keller, K.L. (2003). Strategic Brand Management ; Building, Measuring and Managing Brand Equity. 2nd ed. Upper Saddle River NJ : Prentice Hall.

[19]. Kempen, L.V. (2004). Are the Poor Willing to Pay a Premium for Designer Labels? A Field Experiment in Bolivia. Oxford Development Studies, 32 (2), 205-224.

[20]. Khan, N., Rahmani, S.H.R., Hoe1, H.Y., \& Chen, T.B. (2014). Causal Relationships among Dimensions of Consumer-Based Brand Equity and Purchase Intention: Fashion Industry. Canadian Center of Science and Education, 2014

[21]. Korchia, M. (2004). Brand Image and Brand Association. France: Graduate School of Economy and Management ESSEC University.

[22]. Kotler, P. (2004). Marketing Management (11 ${ }^{\text {th }}$ Ed.). New Jersey: Pearson Prentice Hall.

[23]. Kotler, P., \& Armstrong, G. (2008). Prinsip-prinsip Pemasaran. Jilid 1. Edisi keduabelas. Jakarta : Erlangga

[24]. Korchia, M. (2004). Brand Image and Brand Association. France: Graduate School of Economy and Management ESSEC University.

[25]. Lindawati. (2005). Analisis Kesadaran Merek, Persepsi Kualitas, dan Asosiasi Merek dalam Extensi Merek pada Produk Merek Nokia di Surabaya. Jurnal Sains Pemasaran Indonesia, Vol. IV, No. 1, Mei 2005, hal. 47-70.

[26]. Malhotra, N.K. (2004). Marketing Research: An Applied Orientation. New Jersey: Prentice Hall.

[27]. Moradi, A., \& Zarei, A. (2011). The Impact of Brand Equity on Purchase Intention and Brand Preference-the Moderating Effects of Country of Origin Image. Australian Journal of Basic and Applied Sciences, 5(3): 539-545.

[28]. Muafi., \& Effendi, M.I. (2001). Mengelola Ekuitas Merek: Upaya Memenangkan Persaingan di Era Global. EKOBIS. Vol.2. No.3.

[29]. Netemeyer, R.G., Krishnan, B., Pullig, C., Wang, G., Yagci, M., Dean, D., Ricks, \& Wirth. (2004). Developing and Validating Measures of Facets of Customer-Based Brand Equity. Journal of Business Research, 57 (2), 209-224.

[30]. Porral, C.P., Bourgault, N., \& Dopico, D.C. (2013). Brewing the Recipe for Beer Brand Equity.European Research Studies, pp. 8297 Volume XVI, Issue (2).

[31]. Rio, D.A.B., Vazquez, R., \& Iglesias, V. (2001). The Effect of Brand Association on Consumer Response. Journal of Consumer Marketing. Volume 18, No. 5, hal. $410-425$.

[32]. Schiffman, L.G., \& Kanuk, L.L. (2009). Consumer Behavior. New Jersey : Prentice Hall.

[33]. Senthilnatha, S., \& Tharmi, U. (2011). The Relationship of Brand Equity to Purchase Intention. The IUP Journal of Marketing Management, Vol. XI, No. 2 
[34]. Sethuraman, R., dan Cole, C. (1999). Factors Influencing the Price Premiums that Consumers Pay for National Brands Over Store Brands. Journal of Product \& Brand Management, 8 (4), 340-351.

[35]. Subramaniam, A., Mamun, A.A., Permarupan, P., dan Zainol, N.R.B. (2014). Effects of Brand loyalty Image and Quality on Brand Equity: A Study among Bank Islam Consumers in Kelantan, Malaysia. Canadian Center of Science and Education.

[36]. Vakratsas, D. \& Ambler, T. (1999). How Advertising Works: What Do We Really Know?. Journal of Marketing, January.

[37]. Zeithaml, V. A. (1988). Consumer Perception of Price, Quality, and Value: a Means-end Model and Synthesis of Evidence. Journal of Marketing, 52, pp. 2-11 